\title{
Retraction Note to: ANFIS-based prediction of the compressive strength of geopolymers with seeded fly ash and rice husk-bark ash
}

\author{
Ali Nazari ${ }^{1} \cdot$ Gholamreza Khalaj $^{1} \cdot$ Shadi Riahi $^{1}$
}

Published online: 2 May 2020

(c) Springer-Verlag London Ltd., part of Springer Nature 2020

\section{Retraction to: Neural Comput \& Applic (2013) 22:689-701}

https://doi.org/10.1007/s00521-011-0751-y

The Editor-in-Chief has retracted this article [1] because it significantly overlaps with a number of articles including those that were under consideration at the same time [2-4] and previously published articles [5,6]. Additionally, the article shows evidence of peer review manipulation and authorship manipulation. The authors have not responded to any correspondence regarding this retraction.

\section{References}

1. Nazari A, Khalaj G, Riahi S (2013) ANFIS-based prediction of the compressive strength of geopolymers with seeded fly ash and rice husk-bark ash. Neural Comput Appl 22:689-701. https://doi.org/ 10.1007/s00521-011-0751-y

2. Nazari A, Riahi S (2013) Artificial neural networks to prediction total specific pore volume of geopolymers produced from waste ashes. Neural Comput Appl 22:719-729. https://doi.org/10.1007/ s00521-011-0760-x

3. Nazari A, Khalaj G, Riahi S, Bohlooli H, Kaykha MM (2012) Prediction total specific pore volume of geopolymers produced from waste ashes by ANFIS. Ceram Int 38(4):3111-3120. https:// doi.org/10.1016/j.ceramint.2011.12.011

4. Bohlooli H, Nazari A, Khalaj G, Kaykha MM, Riahi S (2012) RETRACTED: Experimental investigations and fuzzy logic modeling of compressive strength of geopolymers with seeded fly ash and rice husk bark ash. Compos B Eng 43(3):1293-1301. https:// doi.org/10.1016/j.compositesb.2012.01.012

5. Nazari A, Aghazadeh J, Riahi S (2011) RETRACTED: Modified modeling fracture toughness of functionally graded steels in crack divider configuration. Int J Damage Mech 20(6):811-830. https:// doi.org/10.1177/1056789510382851

6. Nazari A, Riahi S (2012) RETRACTED: Experimental investigations and ANFIS prediction of water absorption of geopolymers produced by waste ashes. J Non-Cryst Solids 358(1):40-46. https:// doi.org/10.1016/j.jnoncrysol.2011.08.022

Publisher's Note Springer Nature remains neutral with regard to jurisdictional claims in published maps and institutional affiliations.
The original article can be found online at https:// doi.org/10.1007/s00521-011-0751-y.

\section{Ali Nazari}

alinazari84@aut.ac.ir

1 Department of Materials Engineering, Science and Research branch, Islamic Azad University, Tehran, Iran 